\title{
Leaching of Phosphorus from Quenched Steelmaking Slags with Different Composition
}

\author{
Ning-Ning $\mathrm{Lv}^{1,2}$, Chuan-Ming Du ${ }^{3, * \mathbb{D}}$, Hui Kong ${ }^{1,2}$ and Yao-Hui $\mathrm{Yu}^{3}$ \\ 1 Key Laboratory of Metallurgical Emission Reduction \& Resources Recycling, Anhui University of Technology, \\ Ministry of Education, Maanshan 243002, China; lvning198565@163.com (N.-N.L.); \\ konghui@ahut.edu.cn (H.K.) \\ 2 School of Metallurgical Engineering, Anhui University of Technology, Maanshan 243032, China \\ 3 School of Metallurgy, Northeastern University, Shenyang 110819, China; 2010744@stu.neu.edu.cn \\ * Correspondence: duchuanming@smm.neu.edu.cn; Tel.: +86-155-2418-9830
}

check for updates

Citation: Lv, N.-N.; Du, C.-M.; Kong, H.; Yu, Y.-H. Leaching of Phosphorus from Quenched Steelmaking Slags with Different Composition. Metals 2021, 11, 1026. https://doi.org/ $10.3390 /$ met11071026

Academic Editors: Dariush Azizi and Anna Kaksonen

Received: 26 May 2021

Accepted: 22 June 2021

Published: 25 June 2021

Publisher's Note: MDPI stays neutral with regard to jurisdictional claims in published maps and institutional affiliations.

Copyright: (c) 2021 by the authors. Licensee MDPI, Basel, Switzerland. This article is an open access article distributed under the terms and conditions of the Creative Commons Attribution (CC BY) license (https:/ / creativecommons.org/licenses/by/ $4.0 /)$.

\begin{abstract}
Separating $\mathrm{P}_{2} \mathrm{O}_{5}$ from steelmaking slag is the key to achieving optimum resource utilization of slag. If the P-concentrating $2 \mathrm{CaO} \cdot \mathrm{SiO}_{2}-3 \mathrm{CaO} \cdot \mathrm{P}_{2} \mathrm{O}_{5}$ solid solution was effectively separated, it can be a potential phosphate resource and the remaining slag rich in $\mathrm{Fe}_{2} \mathrm{O}_{3}$ and $\mathrm{CaO}$ can be reutilized as a flux in steelmaking process. In this study, a low-cost method of selective leaching was adopted, and hydrochloric acid was selected as leaching agent. The dissolution behavior of quenched steelmaking slags with different composition in the acidic solution was investigated and the dissolution mechanism was clarified. It was found that the P dissolution ratio from each slag was higher than those of other elements, achieving an effective separation of $\mathrm{P}$ and Fe. The dissolution ratios of $\mathrm{P}, \mathrm{Ca}$, and $\mathrm{Si}$ decreased as the $\mathrm{P}_{2} \mathrm{O}_{5}$ content in slag increased. A higher $\mathrm{Fe}_{2} \mathrm{O}_{3}$ content in slag led to a lower $\mathrm{P}$ dissolution ratio. Increasing slag basicity facilitated the dissolution of $\mathrm{P}$ from slag. The residue mainly composed of matrix phase and the $\mathrm{P}_{2} \mathrm{O}_{5}$ content decreased significantly through selective leaching. The $\mathrm{P}$ dissolution ratio from slag was primarily determined by the $\mathrm{P}$ distribution ratio in the $2 \mathrm{CaO} \cdot \mathrm{SiO}_{2}-3 \mathrm{CaO} \cdot \mathrm{P}_{2} \mathrm{O}_{5}$ solid solution and the precipitation of ferric phosphate in the leachate. The P-concentrating solid solution was effectively separated from quenched steelmaking slag, even though hydrochloric acid was used as leaching agent.
\end{abstract}

Keywords: steelmaking slag; phosphorus; leaching; $2 \mathrm{CaO} \cdot \mathrm{SiO}_{2}-3 \mathrm{CaO} \cdot \mathrm{P}_{2} \mathrm{O}_{5}$

\section{Introduction}

Phosphorus is a significant nutrient element for animal and plant growth; however, it is one of the most detrimental impurities in the iron and steel industry, and most of the phosphorus is eliminated into slag in the steelmaking process [1]. To improve dephosphorization efficiency and reduce slag generation, hot metal dephosphorization was developed in Japan and widely adopted in steel plants [2]. In this process, dephosphorization and decarburization was conducted in converter, respectively, and dephosphorization slag and converter slag were generated [3]. Due to lower $\mathrm{P}_{2} \mathrm{O}_{5}$ content, converter slag can be recycled as a flux in dephosphorization process, and then only dephosphorization slag with relatively low basicity is emitted. The hot metal dephosphorization slag normally consists of $\mathrm{CaO}-\mathrm{SiO}_{2}-\mathrm{FeO}-\mathrm{P}_{2} \mathrm{O}_{5}$ system, and the industrial operation is mainly carried out in the dicalcium silicate $\left(2 \mathrm{CaO} \cdot \mathrm{SiO}_{2}\right)$-saturated composition range $[4,5]$. The amount of steelmaking slag is approximately $100 \sim 150 \mathrm{~kg}$ of per ton of steel [6], while the utilization ratio of steelmaking slag is not high. Large amounts of steelmaking slag are piled up or landfilled directly, causing tremendous waste of valuable components.

As the utilization of iron ores with higher $\mathrm{P}$ content, the $\mathrm{P}_{2} \mathrm{O}_{5}$ content in steelmaking slag is continuously increasing, and then steelmaking slag is regarded an important material to substitute for phosphate rocks [7]. It is well known that $2 \mathrm{CaO} \cdot \mathrm{SiO}_{2}$ forms a solid solution with tricalcium phosphate $\left(3 \mathrm{CaO} \cdot \mathrm{P}_{2} \mathrm{O}_{5}\right)$ at the treatment temperature over a wide 
composition range [8,9]. This implies that the product of dephosphorization reaction can be concentrated in the $2 \mathrm{CaO} \cdot \mathrm{SiO}_{2}-3 \mathrm{CaO} \cdot \mathrm{P}_{2} \mathrm{O}_{5}\left(\mathrm{C}_{2} \mathrm{~S}-\mathrm{C}_{3} \mathrm{P}\right)$ solid solution, which provides the foundation for $\mathrm{P}$ recovery. The P-concentrating $\mathrm{C}_{2} \mathrm{~S}-\mathrm{C}_{3} \mathrm{P}$ solid solution separated from slag can be used as phosphate resource and the remaining slag rich in $\mathrm{Fe}_{t} \mathrm{O}$ and $\mathrm{CaO}$ can be reutilized as a flux in the ironmaking and steelmaking process, achieving the comprehensive utilization of steelmaking slag.

Various studies have been conducted on the removal of phosphorus from steelmaking slag. Li et al. [10] used centrifugal separation to remove $\mathrm{C}_{2} \mathrm{~S}-\mathrm{C}_{3} \mathrm{P}$ solid solution from the molten slag at high temperature according to the density differences for different mineral phases. Kubo et al. [11] and Lin et al. [12] studied the removal of $\mathrm{nC}_{2} \mathrm{~S}-\mathrm{C}_{3} \mathrm{P}$ solid solution from steelmaking slag according to the differences in the magnetic properties of mineral phases. Recently, some researchers focused on the P recovery from steelmaking slag using acid leaching. Numata et al. [13] reported that in the case of $\mathrm{Fe}_{2} \mathrm{O}_{3}$-containing slag, the dissolution ratio of each element in the matrix phase was lower than that in the solid solution at various $\mathrm{pH}$ conditions. Qiao et al. [14] investigated the dissolution behavior of slag in the buffer solution of $\mathrm{C}_{6} \mathrm{H}_{8} \mathrm{O}_{7}-\mathrm{NaOH}-\mathrm{HCl}$ system and found that most of the $\mathrm{P}$ was dissolved while the Fe dissolution ratio was also high. Du et al. $[15,16]$ clarified that $\mathrm{Na}_{2} \mathrm{O}$ modification and oxidization of molten slag was beneficial for the dissolution of $\mathrm{C}_{2} \mathrm{~S}-\mathrm{C}_{3} \mathrm{P}$ solid solution from steelmaking slag with high $\mathrm{P}_{2} \mathrm{O}_{5}$ content in the citric acid solution. Under the optimum conditions, the P dissolution ratio exceeded $85 \%$ and the dissolution of Fe was negligible, achieving selective leaching of P. After leaching, most of the P dissolved in leachate can be recovered as calcium phosphates by chemical precipitation, illustrating that acid leaching is an effective and low-cost method to recover P from steelmaking slag [17].

Concerning steelmaking slag with high $\mathrm{P}_{2} \mathrm{O}_{5}$ content, previous studies primarily studied the selective leaching of $P$ from the furnace-cooled slag in the citric acid solution. Because of slow cooling and the use of organic acid, it resulted in a high treatment cost. In this study, to reduce treatment cost, hydrochloric acid $(\mathrm{HCl})$ was selected as a leaching agent and the quenched slag from dephosphorization process was used. The dissolution behavior of $P$ from quenched steelmaking slags with different composition were investigated. The aim of this study is to achieve an efficient separation of $P$ from steelmaking slag with a simple and low-cost method. It is expected that this will provide theoretical and technical basis for the high value-added utilization of steelmaking slag.

\section{Experimental}

As reported in previous studies [17,18], the existence of $\mathrm{Fe}_{2} \mathrm{O}_{3}$ and $\mathrm{Na}_{2} \mathrm{O}$ modification was beneficial for the selective leaching of $\mathrm{P}$ from slag. In this study, slag composition was simplified, and dephosphorization slags consisting of $\mathrm{CaO}-\mathrm{SiO}_{2}-\mathrm{Fe}_{2} \mathrm{O}_{3}-\mathrm{P}_{2} \mathrm{O}_{5}-\mathrm{Na}_{2} \mathrm{O}$ system were used. Compared with converter slag, these slags had relatively low slag basicity. Eight kinds of slags with different $\mathrm{P}_{2} \mathrm{O}_{5}, \mathrm{Fe}_{2} \mathrm{O}_{3}$, and basicity $\left(\mathrm{CaO} / \mathrm{SiO}_{2}\right)$ were synthesized using reagent-grade $\mathrm{CaCO}_{3}, \mathrm{SiO}_{2}, \mathrm{Fe}_{2} \mathrm{O}_{3}, \mathrm{Ca}_{3}\left(\mathrm{PO}_{4}\right)_{2}$, and $\mathrm{Na}_{2} \mathrm{SiO}_{3}$. The mixed chemical reagents were firstly heated to $1823 \mathrm{~K}$ to form a homogeneous liquid slag in a $\mathrm{Pt}$ crucible under air. Then, it was cooled to $1673 \mathrm{~K}$ at a cooling rate of $3 \mathrm{~K} / \mathrm{min}$ and held 20 min to precipitate the $\mathrm{C}_{2} \mathrm{~S}-\mathrm{C}_{3} \mathrm{P}$ solid solution. Finally, slag was quickly taken out of the furnace and quenched in water. The synthesized slag was ground and sieved into particles of less than $53 \mu \mathrm{m}$. After performing aqua-regia digestion, the element concentration in each slag was determined using inductively coupled plasma atomic emission spectroscopy (ICP-AES) (SPECTRO, Kleve, Germany). Table 1 lists the actual composition of synthesized steelmaking slags. The mineralogical composition and morphology of mineral phases in slag was determined using X-ray diffraction (XRD) (Rigaku Corporation, Tokyo, Japan) analysis and electron probe microanalysis (EPMA) (JEOL, Tokyo, Japan). 
Table 1. Actual composition of synthesized slags (mass $\%$ ).

\begin{tabular}{ccccccc}
\hline No. & $\mathbf{C a O}$ & $\mathbf{S i O}_{\mathbf{2}}$ & $\mathbf{F e}_{\mathbf{2}} \mathbf{O}_{\mathbf{3}}$ & $\mathbf{P}_{\mathbf{2}} \mathbf{O}_{\mathbf{5}}$ & $\mathbf{N a}_{\mathbf{2}} \mathbf{O}$ & $\begin{array}{c}\text { Basicity } \\
\text { (C/S) }\end{array}$ \\
\hline Slag 1 & 42.1 & 24.6 & 20.4 & 7.6 & 5.3 & 1.71 \\
Slag 2 & 40.7 & 23.9 & 19.6 & 10.5 & 5.3 & 1.70 \\
Slag 3 & 39.3 & 23.1 & 19.1 & 13.3 & 5.2 & 1.70 \\
Slag 4 & 38.0 & 22.1 & 18.2 & 16.3 & 5.4 & 1.72 \\
Slag 5 & 43.8 & 25.6 & 14.9 & 10.4 & 5.3 & 1.71 \\
Slag 6 & 37.2 & 21.6 & 25.4 & 10.3 & 5.5 & 1.72 \\
Slag 7 & 38.5 & 26.3 & 19.8 & 10.1 & 5.3 & 1.46 \\
Slag 8 & 42.4 & 22.1 & 19.9 & 10.4 & 5.2 & 1.92 \\
\hline
\end{tabular}

A Teflon vessel containing $300 \mathrm{~mL}$ of distilled water was placed in an isothermal water bath. $1.5 \mathrm{~g}$ of slag was added to keep the mass ratio (slag to solution) as 1:200 to cause the slag to fully dissolve, as described in previous study [19]. The slurry was agitated using a rotating stirrer at $200 \mathrm{rpm}$ at room temperature $(298 \mathrm{~K})$. The diluted hydrochloric acid $(0.4 \mathrm{~mol} / \mathrm{L})$ was used as a leaching agent and it was added to the slurry by a $\mathrm{pH}$ control and solution addition system. In previous study [18], most of the P could be dissolved from the furnace-cooled slag at $\mathrm{pH} 4$. Hence, the $\mathrm{pH}$ of slurry was maintained at 4 to achieve the selective leaching of P. At appropriate intervals, approximately $4 \mathrm{~mL}$ of slurry was sampled, and filtered using a syringe filter $(<0.45 \mu \mathrm{m})$. The concentration of each element in the leachate was analyzed using ICP-AES. After $120 \mathrm{~min}$, the slurry was separated by vacuum filtration and the obtained residue was dried at $373 \mathrm{~K}$. The residue was weighed and analyzed by XRD and EPMA. The chemical composition of residue was determined using the same method for slag analysis.

The dissolution ratio of element $\mathrm{X}\left(R_{\mathrm{X}}\right)$ from steelmaking slag was calculated using the element concentration in the leachate, as expressed in Equation (1):

$$
R_{\mathrm{X}}=\frac{C_{\mathrm{X}} \cdot V \cdot M_{\mathrm{XO}}}{m \cdot w_{\mathrm{XO}} \cdot M_{\mathrm{X}}}
$$

where $C_{X}$ is the element $\mathrm{X}$ concentration in the leachate $(\mathrm{mg} / \mathrm{L}) ; V$ is the final leachate volume (L); $m$ is the slag mass $(\mathrm{mg}) ; w_{X O}$ is the oxide $X O$ content in slag; $M$ is molar mass.

\section{Results}

\subsection{Mineralogical Composition}

The morphology of mineral phases in synthesized slags with various composition is shown in Figure 1. Each slag principally composed of two mineral phases, and the mass fractions of mineral phases in different slag were obviously different. Table 2 lists the average composition of each mineral phase in slag. The black mineral phase consisting of CaO- $\mathrm{SiO}_{2}-\mathrm{P}_{2} \mathrm{O}_{5}$ slag system is considered the $\mathrm{C}_{2} \mathrm{~S}-\mathrm{C}_{3} \mathrm{P}$ solid solution; the grey mineral phase consisting of $\mathrm{CaO}-\mathrm{SiO}_{2}-\mathrm{Fe}_{2} \mathrm{O}_{3}$ slag system is regarded the amorphous matrix phase. The high distribution ratio of $\mathrm{P}_{2} \mathrm{O}_{5}$ between the solid solution and the matrix phase indicated that the majority of $\mathrm{P}_{2} \mathrm{O}_{5}$ was concentrated in the $\mathrm{C}_{2} \mathrm{~S}-\mathrm{C}_{3} \mathrm{P}$ solid solution. The enrichment of $\mathrm{P}_{2} \mathrm{O}_{5}$ and $\mathrm{Fe}_{2} \mathrm{O}_{3}$ in different mineral phases was the basis of $\mathrm{P}$ separation by selective leaching. A part of $\mathrm{Na}_{2} \mathrm{O}$ was also distributed in the $\mathrm{C}_{2} \mathrm{~S}-\mathrm{C}_{3} \mathrm{P}$ solid solution, which could promote the dissolution of solid solution. As the $\mathrm{P}_{2} \mathrm{O}_{5}$ content in slag increased, the $\mathrm{P}_{2} \mathrm{O}_{5}$ contents in the solid solution and in the matrix phase both increased. In the case of Slag 4, containing $16.3 \% \mathrm{P}_{2} \mathrm{O}_{5}$, the solid solution almost consisted of $3 \mathrm{CaO} \cdot \mathrm{P}_{2} \mathrm{O}_{5}$. As the $\mathrm{Fe}_{2} \mathrm{O}_{3}$ content in slag increased, the $\mathrm{P}_{2} \mathrm{O}_{5}$ content in the solid solution increased, whereas that in the matrix phase had little change. The $\mathrm{P}_{2} \mathrm{O}_{5}$ contents in the solid solution and in the matrix phase both decreased with the increase in slag basicity, but the distribution ratio of $\mathrm{P}_{2} \mathrm{O}_{5}$ was still high. If $\mathrm{P}_{2} \mathrm{O}_{5}$ was sufficiently concentrated in the $\mathrm{C}_{2} \mathrm{~S}-\mathrm{C}_{3} \mathrm{P}$ solid solution which could be fully dissolved, separation of $\mathrm{P}$ from steelmaking slag could be achieved. 


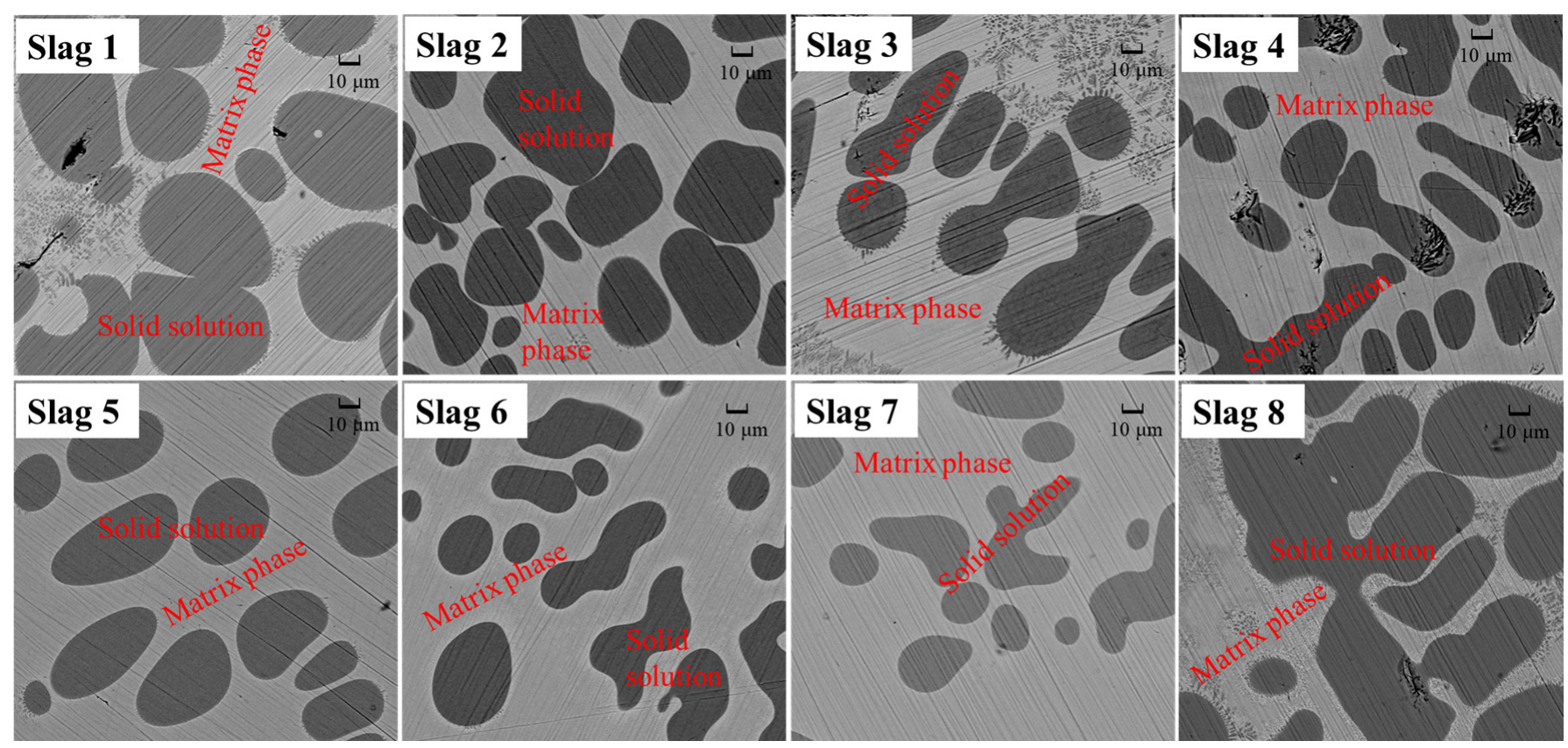

Figure 1. Morphology of mineral phases in the quenched steelmaking slags (EPMA analysis).

Table 2. Average composition of each phase in steelmaking slag (mass\%).

\begin{tabular}{|c|c|c|c|c|c|c|}
\hline & & $\mathrm{CaO}$ & $\mathrm{SiO}_{2}$ & $\mathrm{Fe}_{2} \mathrm{O}_{3}$ & $\mathbf{P}_{2} \mathrm{O}_{5}$ & $\mathrm{Na}_{2} \mathrm{O}$ \\
\hline \multirow{8}{*}{ Solid Solution } & Slag 1 & 54.8 & 22.4 & 1.2 & 16.2 & 5.4 \\
\hline & Slag 2 & 52.3 & 14.7 & 1.1 & 25.1 & 6.7 \\
\hline & Slag 3 & 49.9 & 10.2 & 1.0 & 32.1 & 6.8 \\
\hline & Slag 4 & 48.0 & 5.7 & 0.9 & 38.5 & 6.8 \\
\hline & Slag 5 & 52.6 & 19.2 & 1.1 & 21.2 & 6.0 \\
\hline & Slag 6 & 48.1 & 12.6 & 1.0 & 30.2 & 8.0 \\
\hline & Slag 7 & 50.7 & 12.1 & 1.1 & 29.4 & 6.8 \\
\hline & Slag 8 & 53.7 & 18.7 & 1.1 & 20.8 & 5.8 \\
\hline \multirow{8}{*}{ Matrix Phase } & Slag 1 & 32.7 & 28.2 & 32.5 & 1.7 & 4.9 \\
\hline & Slag 2 & 35.3 & 28.6 & 27.8 & 4.0 & 4.3 \\
\hline & Slag 3 & 34.1 & 29.1 & 27.0 & 5.5 & 4.2 \\
\hline & Slag 4 & 32.2 & 30.7 & 26.2 & 6.4 & 4.4 \\
\hline & Slag 5 & 34.9 & 31.7 & 24.9 & 3.9 & 4.5 \\
\hline & Slag 6 & 31.0 & 26.1 & 34.5 & 4.0 & 4.4 \\
\hline & Slag 7 & 35.8 & 30.7 & 22.5 & 6.7 & 4.4 \\
\hline & Slag 8 & 33.4 & 26.5 & 33.1 & 2.9 & 4.1 \\
\hline
\end{tabular}

\subsection{Leaching Results}

The effect of $\mathrm{P}_{2} \mathrm{O}_{5}$ content on the change in $\mathrm{Ca}$ and $\mathrm{P}$ concentrations with leaching time is shown in Figure 2a. The dissolution of each slag primarily occurred in the initial period, resulting in significant increase in $\mathrm{Ca}$ and $\mathrm{P}$ concentrations. Their concentrations had a little increase after $60 \mathrm{~min}$. With the increase in $\mathrm{P}_{2} \mathrm{O}_{5}$ content in slag, the $\mathrm{P}$ concentration increased significantly in the leachate, while the Ca concentration decreased. For Slag 4, containing $16.3 \% \mathrm{P}_{2} \mathrm{O}_{5}$, the $\mathrm{Ca}$ and $\mathrm{P}$ concentrations reached $507.4 \mathrm{mg} / \mathrm{L}$ and $211.8 \mathrm{mg} / \mathrm{L}$, respectively, after $120 \mathrm{~min}$. The calculated dissolution ratios of main elements from slag are shown in Figure 2b. It is worth noting that these elements presented different dissolution 
behavior. The $\mathrm{P}$ dissolution ratio was the highest, and it was approximately $70 \%$ in the case of Slag 1. Fe was hard to dissolve, and its dissolution ratio was almost zero. As the $\mathrm{P}_{2} \mathrm{O}_{5}$ content in slag increased, the dissolution ratios of $\mathrm{P}, \mathrm{Ca}$, and $\mathrm{Si}$ all decreased, indicating that slag dissolution became difficult. Compared with the leaching results of furnace-cooled slag in the citric acid solution [17], the P dissolution ratio was a little lower, but the dissolution of Fe was negligible, achieving an effective separation of $\mathrm{P}$ and $\mathrm{Fe}$ as well. The majority of $\mathrm{P}$ was dissolved from each slag without a large dissolution of other elements.
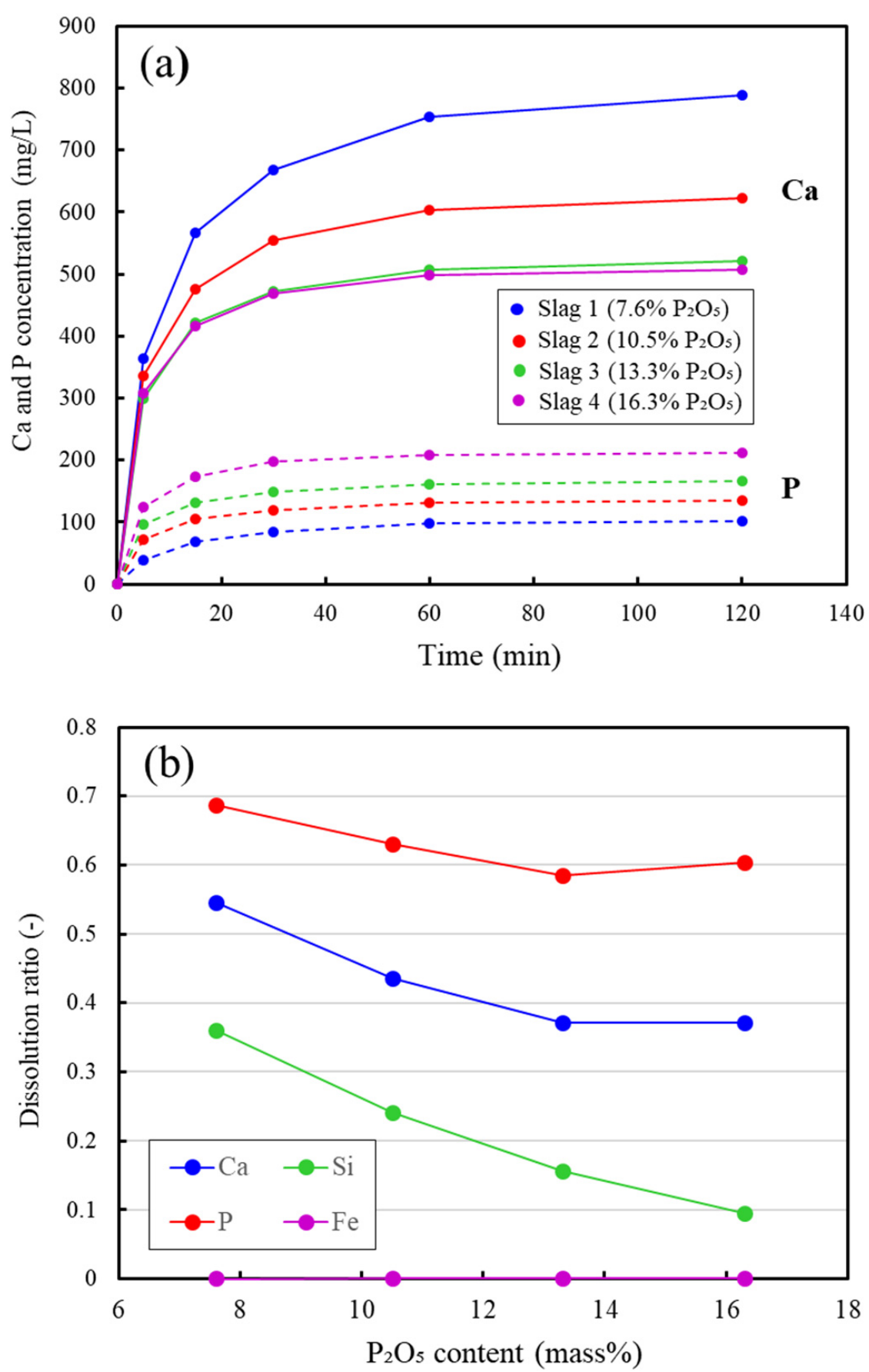

Figure 2. (a) Change in the $\mathrm{Ca}$ and $\mathrm{P}$ concentrations with leaching time; (b) Dissolution ratios of main elements from slags with different $\mathrm{P}_{2} \mathrm{O}_{5}$ contents. 
Figure 3a shows the change in $\mathrm{Ca}$ and $\mathrm{P}$ concentrations with time when slags with different $\mathrm{Fe}_{2} \mathrm{O}_{3}$ contents were leached. With the increase in $\mathrm{Fe}_{2} \mathrm{O}_{3}$ content, the Ca concentration in the leachate decreased, whereas the $\mathrm{P}$ concentration showed little change, approximately $140 \mathrm{mg} / \mathrm{L}$ after $120 \mathrm{~min}$. The dissolution ratios of the main elements from slags with different $\mathrm{Fe}_{2} \mathrm{O}_{3}$ contents are presented in Figure $3 \mathrm{~b}$. The dissolution of $\mathrm{Fe}$ was very difficult regardless of $\mathrm{Fe}_{2} \mathrm{O}_{3}$ content. When the $\mathrm{Fe}_{2} \mathrm{O}_{3}$ content increased from $14.9 \%$ to $19.6 \%$, the $\mathrm{Ca}$ and $\mathrm{Si}$ dissolution ratios decreased dramatically, while the P dissolution ratio decreased by only $3 \%$. If the $\mathrm{Fe}_{2} \mathrm{O}_{3}$ content continued to increase, it had a little influence on the dissolution ratio. Although increasing $\mathrm{Fe}_{2} \mathrm{O}_{3}$ content slightly decreased $\mathrm{P}$ dissolution, it significantly suppressed the dissolution of other elements, which was beneficial for selective leaching.
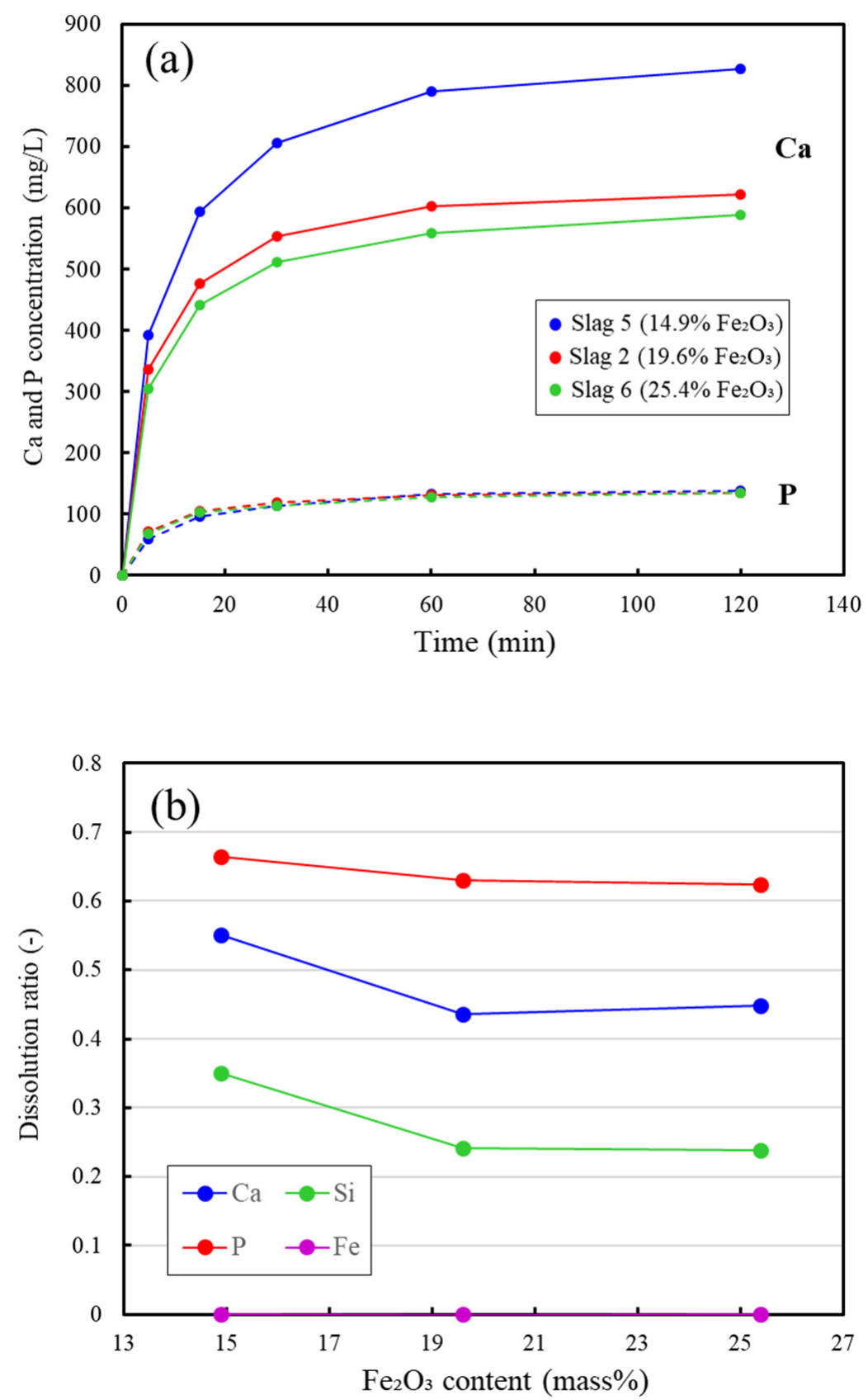

Figure 3. (a) Change in the $\mathrm{Ca}$ and $\mathrm{P}$ concentrations with leaching time; (b) Dissolution ratios of main elements from slag with different $\mathrm{Fe}_{2} \mathrm{O}_{3}$ contents. 
The effect of slag basicity on the dissolution behavior of slag is shown in Figure 4 . The $\mathrm{Ca}$ and $\mathrm{P}$ concentrations both increased significantly with slag basicity. The increasing tendency toward dissolution ratios of $\mathrm{P}, \mathrm{Ca}$, and $\mathrm{Si}$ was almost the same. In the case of low basicity, the dissolution of slag was difficult, resulting in a lower P dissolution ratio. When slag basicity increased to 1.92 , the $\mathrm{P}$ dissolution ratio reached $77.4 \%$ and Fe did not dissolve, illustrating that selective leaching was achieved. The $\mathrm{Ca}$ and $\mathrm{Si}$ dissolution ratios were $61.7 \%$ and $42.2 \%$, respectively. These results suggest that increasing slag basicity facilitates the dissolution of $\mathrm{P}$ from slag. Combining with mineralogical composition, it was found that a higher $\mathrm{P}_{2} \mathrm{O}_{5}$ content in the $\mathrm{C}_{2} \mathrm{~S}-\mathrm{C}_{3} \mathrm{P}$ solid solution caused lower dissolution ratio of each element from slag. To promote $\mathrm{P}$ dissolution, the $\mathrm{P}_{2} \mathrm{O}_{5}$ content in the solid solution should be lowered.
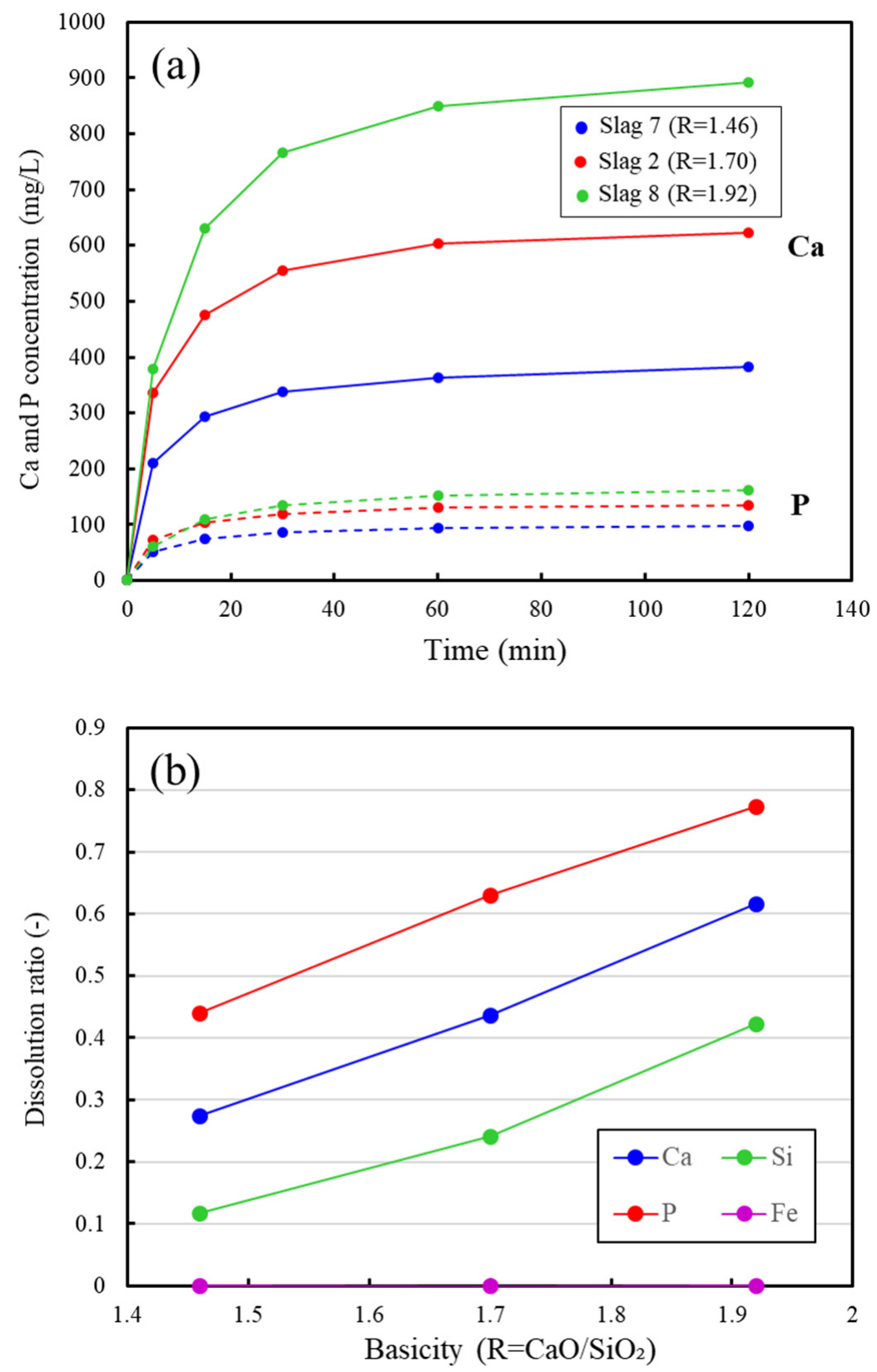

Figure 4. (a) Change in the Ca and P concentrations with leaching time; (b) Dissolution ratios of main elements from slags with different basicity. 


\subsection{Characterization of Residue}

The XRD patterns of Slag 2 and its residue after leaching is shown in Figure 5. For Slag 2, the characteristic peaks associated with $\mathrm{C}_{2} \mathrm{~S}-\mathrm{C}_{3} \mathrm{P}$ solid solution and the broad peaks of non-crystalline phase were observed, confirming the existence of two mineral phases. Following leaching, the characteristic peaks of $\mathrm{C}_{2} \mathrm{~S}-\mathrm{C}_{3} \mathrm{P}$ solid solution all disappeared, and the broad peaks of non-crystalline phase intensified, illustrating that the P-concentrating phase was fully dissolved. Figure 6 shows the morphology of residue after the leaching of Slag 2. This residue consisted of some irregular particles with single mineral phase. As listed in Table 3, this mineral phase mainly containing $\mathrm{CaO}, \mathrm{SiO}_{2}$, and $\mathrm{Fe}_{2} \mathrm{O}_{3}$ was similar to the matrix phase. It indicates that only the matrix phase remains in the residue, which is consistent with the XRD results. The average composition of residue is shown in Table 4. Compared with the composition in Table 1, the $\mathrm{P}_{2} \mathrm{O}_{5}$ content decreased from $10.5 \%$ to $4.3 \%$, proving that the $\mathrm{C}_{2} \mathrm{~S}-\mathrm{C}_{3} \mathrm{P}$ solid solution was effectively separated, while the $\mathrm{Fe}_{2} \mathrm{O}_{3}$ content increased from $19.6 \%$ to $31.0 \%$.

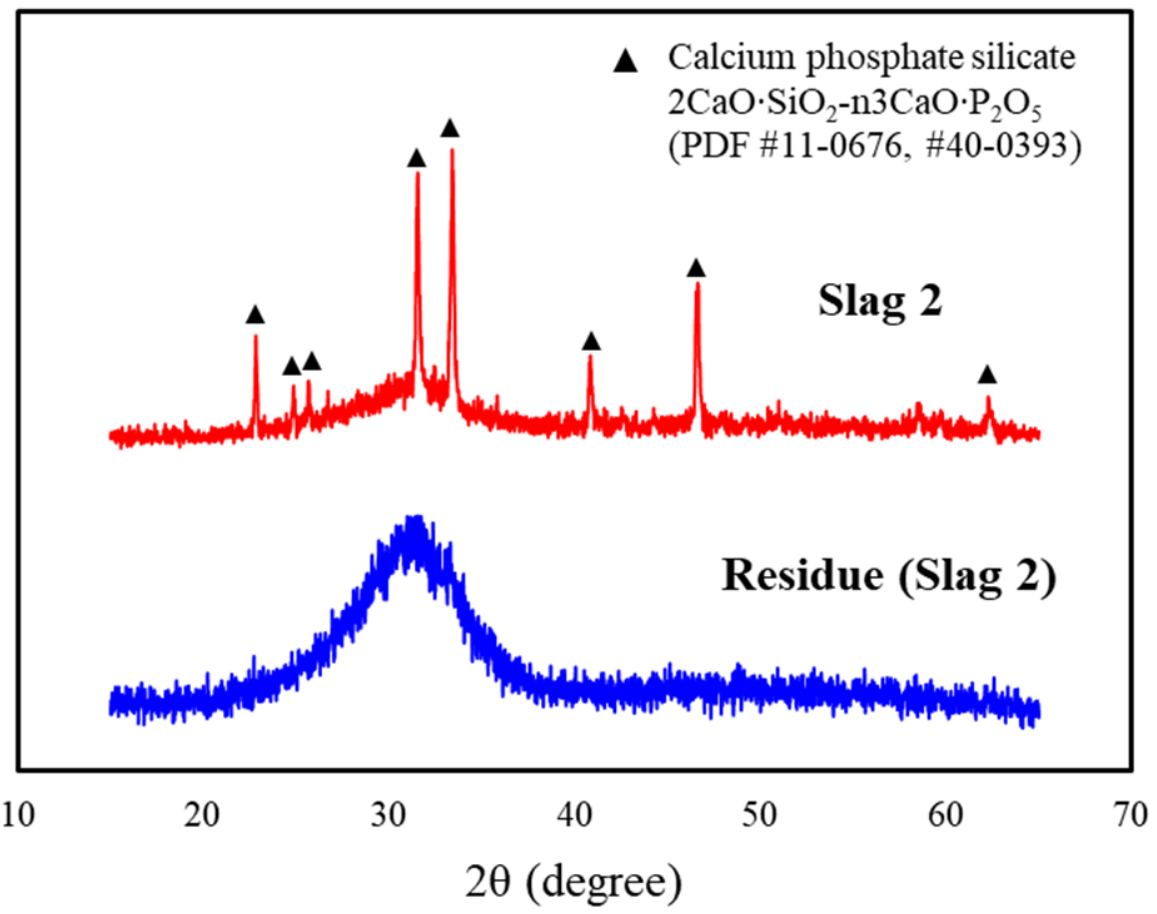

Figure 5. XRD patterns of Slag 2 and its residue after leaching.

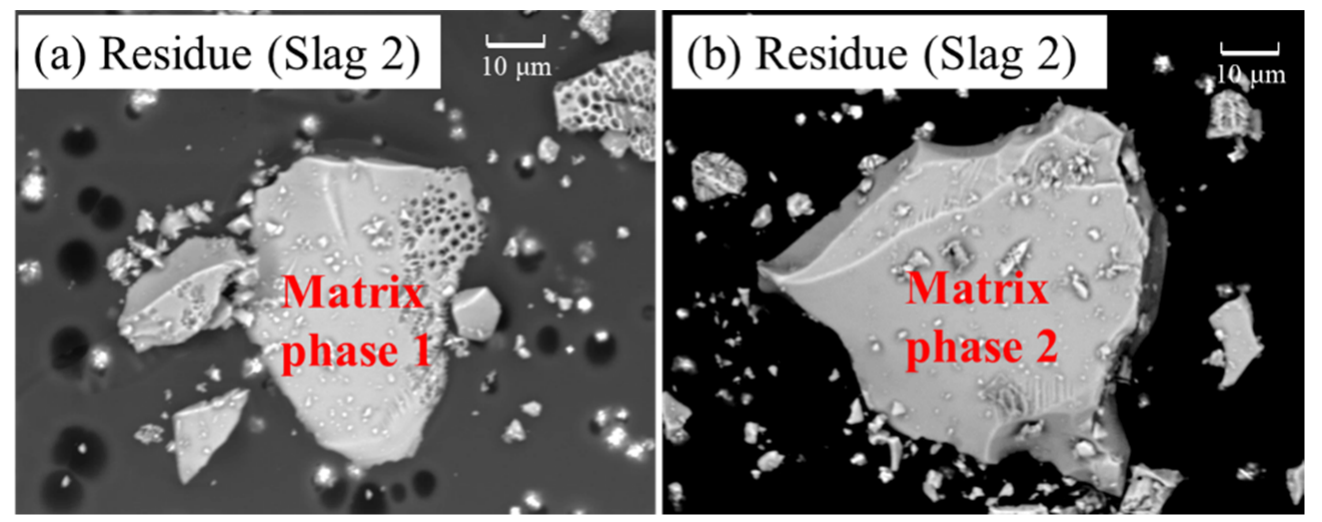

Figure 6. (a,b) Morphology of residue surface of Slag 2 (EPMA analysis). 
Table 3. Average composition of mineral phases on the residue surface (mass \%).

\begin{tabular}{ccccccc}
\hline Matrix Phase & Ca & Si & Fe & P & Na & O \\
\hline 1 & 24.2 & 12.8 & 21.1 & 1.8 & 3.0 & 37.1 \\
2 & 24.2 & 10.1 & 17.6 & 2.1 & 3.4 & 42.6 \\
\hline
\end{tabular}

Table 4. Chemical composition of the residue of Slag 2 (mass $\%$ ).

\begin{tabular}{cccccc}
\hline & $\mathbf{C a O}$ & $\mathbf{S i O}_{2}$ & $\mathbf{F e}_{2} \mathbf{O}_{3}$ & $\mathbf{P}_{\mathbf{2}} \mathbf{O}_{5}$ & $\mathbf{N a}_{\mathbf{2}} \mathbf{O}$ \\
\hline Residue (Slag 2) & 32.9 & 28.2 & 31.0 & 4.3 & 3.6 \\
\hline
\end{tabular}

Overall, in this process, the $\mathrm{P}$-containing leachate can be used to extract calcium phosphates by chemical precipitation, and the residue consisting of $\mathrm{CaO}-\mathrm{SiO}_{2}-\mathrm{Fe}_{2} \mathrm{O}_{3}$ system has lower $\mathrm{P}_{2} \mathrm{O}_{5}$ content, which can be used as a flux in the steelmaking process. These results will promote the comprehensive utilization of steelmaking slag and ease environmental burden.

\section{Discussion}

To achieve the selective leaching of $\mathrm{P}$, the dissolution behavior and mechanism of $P$ from quenched steelmaking slag should be understood. Several kinds of cations and anions exist in the leachate. Since phosphate ions can precipitate with metallic ions, it is necessary to consider the possibility of phosphate formation. In the aqueous solution, hydroxyapatite $\left(\mathrm{Ca}_{10}\left(\mathrm{PO}_{4}\right)_{6}(\mathrm{OH})_{2}\right)$ and strengite $\left(\mathrm{FePO}_{4} \cdot 2 \mathrm{H}_{2} \mathrm{O}\right)$ readily precipitate when $\mathrm{Ca}^{2+}$ and $\mathrm{Fe}^{3+}$ ions coexist with phosphate ions [20]. The precipitation of these phosphates plays a significant role in determining the $\mathrm{P}$ concentration in the leachate. Therefore, we investigated the concentration relationship between phosphate ions and metallic ions in the aqueous solution. There are several types of phosphate ions in the aqueous solution depending on $\mathrm{pH}$, including $\mathrm{PO}_{4}{ }^{3-}, \mathrm{HPO}_{4}{ }^{2-}$, and $\mathrm{H}_{2} \mathrm{PO}_{4}{ }^{-}$[21]. In thermodynamic calculation, these phosphates ions were considered, and the activity coefficients of ions were assumed to be 1 because their concentrations were relatively low. The solubility lines of $\mathrm{FePO}_{4} \cdot 2 \mathrm{H}_{2} \mathrm{O}$ and $\mathrm{Ca}_{10}\left(\mathrm{PO}_{4}\right)_{6}(\mathrm{OH})_{2}$ were calculated using the reaction equilibrium constants of Equations (2)-(5) at $\mathrm{pH} 4$, respectively [22,23].

$$
\begin{gathered}
\mathrm{FePO}_{4} \cdot 2 \mathrm{H}_{2} \mathrm{O}=\mathrm{Fe}^{3+}+\mathrm{PO}_{4}^{3-}+2 \mathrm{H}_{2} \mathrm{O} \log \mathrm{K}=-26.07 \\
\mathrm{Ca}_{2}\left(\mathrm{PO}_{4}\right)_{6}(\mathrm{OH})_{2}+2 \mathrm{H}^{+}=10 \mathrm{Ca}^{2+}+6 \mathrm{PO}_{4}^{3-}+2 \mathrm{H}_{2} \mathrm{O} \log \mathrm{K}=-62.42 \\
\mathrm{PO}_{4}^{3-}+\mathrm{H}^{+}=\mathrm{HPO}_{4}^{2-} \log \mathrm{K}=12.36 \\
\mathrm{PO}_{4}^{3-}+2 \mathrm{H}^{+}=\mathrm{H}_{2} \mathrm{PO}_{4}^{-} \log \mathrm{K}=19.56
\end{gathered}
$$

Figure 7 shows the relationship between $\mathrm{P}$ and $\mathrm{Fe}$ concentrations in the aqueous solution and experimental results. It was found that the solubility of $\mathrm{FePO}_{4} \cdot 2 \mathrm{H}_{2} \mathrm{O}$ was very low at $\mathrm{pH} 4$ and large amounts of phosphate and $\mathrm{Fe}^{3+}$ ions could not coexist in the aqueous solution. The saturation concentration of $\mathrm{P}$ decreased with the increase in $\mathrm{Fe}$ concentration. The P concentration in the leachate was high while the Fe concentration was very low, near zero. The points of experimental result all located above the solubility line of $\mathrm{FePO}_{4} \cdot 2 \mathrm{H}_{2} \mathrm{O}$, indicating that the $\mathrm{P}$ and $\mathrm{Fe}$ concentrations were supersaturated and $\mathrm{FePO}_{4} \cdot 2 \mathrm{H}_{2} \mathrm{O}$ could precipitate. During leaching, the $\mathrm{C}_{2} \mathrm{~S}-\mathrm{C}_{3} \mathrm{P}$ solid solution dissolved well, and the dissolution of the Fe-containing matrix phase was low, resulting in high concentrations of $\mathrm{Ca}, \mathrm{Si}$, and $\mathrm{P}$. As approximately $1.0 \% \mathrm{Fe}_{2} \mathrm{O}_{3}$ existed in the solid solution, some $\mathrm{Fe}$ was also dissolved. However, it was difficult for these $\mathrm{Fe}^{3+}$ ions to coexist with phosphate ions, and then $\mathrm{Fe}^{3+}$ ions precipitated in the form of $\mathrm{FePO}_{4} \cdot 2 \mathrm{H}_{2} \mathrm{O}$. Owing to a small quantity of Fe dissolved from slag, the formation of $\mathrm{FePO}_{4} \cdot 2 \mathrm{H}_{2} \mathrm{O}$ had little influence on the decrease in $\mathrm{P}$ concentration in the leachate. To make phosphate ions exist stably in the leachate, the dissolution of Fe from slag should be suppressed as much as possible. 


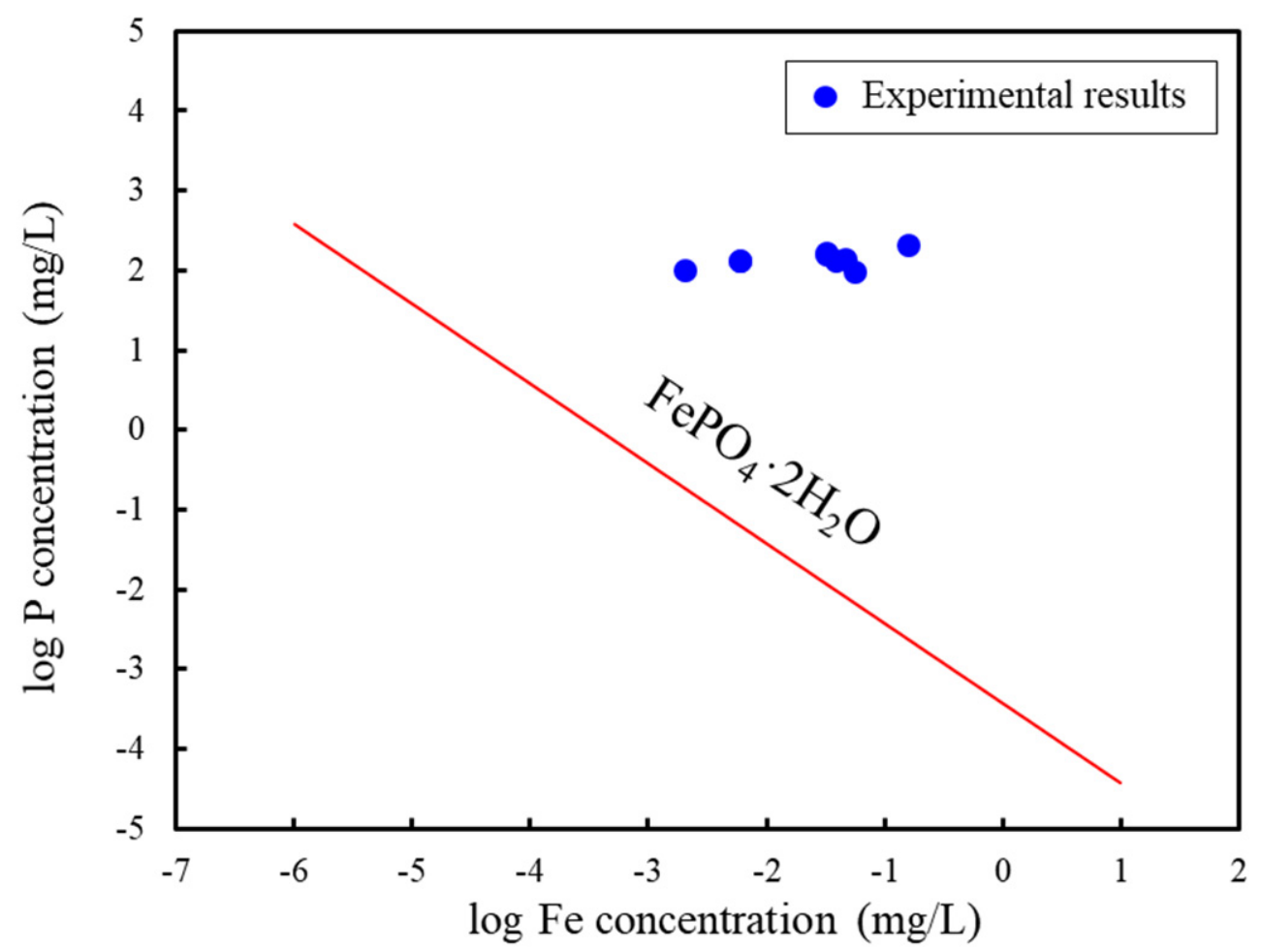

Figure 7. Relationship between $\mathrm{P}$ and Fe concentrations in the aqueous solution and experimental results.

Because the Ca concentration was higher than other elements in the leachate, the possibility of $\mathrm{Ca}_{10}\left(\mathrm{PO}_{4}\right)_{6}(\mathrm{OH})_{2}$ formation was evaluated. As shown in Figure 8, it was difficult for the precipitation of calcium phosphates to occur in the aqueous solution at $\mathrm{pH}$ 4 unless concentrations on $\mathrm{Ca}$ and $\mathrm{P}$ were high. In this study, the maximum $\mathrm{P}$ concentration was $211.8 \mathrm{mg} / \mathrm{L}$ and it was far lower than the saturation concentration. The points of $\mathrm{P}$ and Ca concentrations were located far below the solubility line of $\mathrm{Ca}_{10}\left(\mathrm{PO}_{4}\right)_{6}(\mathrm{OH})_{2}$, illustrating that $\mathrm{Ca}$ concentration has no effect on phosphate precipitation. The $\mathrm{P}$ concentration in the leachate primarily depended on the Fe concentration. Under this condition, most of the $\mathrm{P}$ dissolved from slag existed stably in the leachate, proving that selective leaching of $\mathrm{P}$ from quenched steelmaking slag with high $\mathrm{P}_{2} \mathrm{O}_{5}$ content was possible, even in the hydrochloric acid solution.

To evaluate P-selective leaching from each slag, we compared the $\mathrm{P}$ distribution ratio in the $\mathrm{C}_{2} \mathrm{~S}-\mathrm{C}_{3} \mathrm{P}$ solid solution with the $\mathrm{P}$ dissolution ratio from slag. The mass fractions of solid solution and matrix phase were first calculated using Equations (6) and (7), where $\alpha$ and $\beta$ are the mass fraction of solid solution and matrix phase, respectively, $w_{\mathrm{XO}}^{\alpha}$ and $w_{\mathrm{XO}}^{\beta}$ are the $\mathrm{XO}$ content in the solid solution and matrix phase, respectively. The mass fraction was defined as the average results of each oxide. Then, the $\mathrm{P}$ distribution ratio in the solid solution $(D)$ was calculated using Equation (8).

$$
\begin{gathered}
w_{\mathrm{XO}}=\alpha w_{\mathrm{XO}}^{\alpha}+\beta w_{\mathrm{XO}}^{\beta} \\
\alpha+\beta=1 \\
D=\frac{\alpha w_{\mathrm{P}_{2} \mathrm{O}_{5}}^{\alpha}}{w_{\mathrm{P}_{2} \mathrm{O}_{5}}}
\end{gathered}
$$




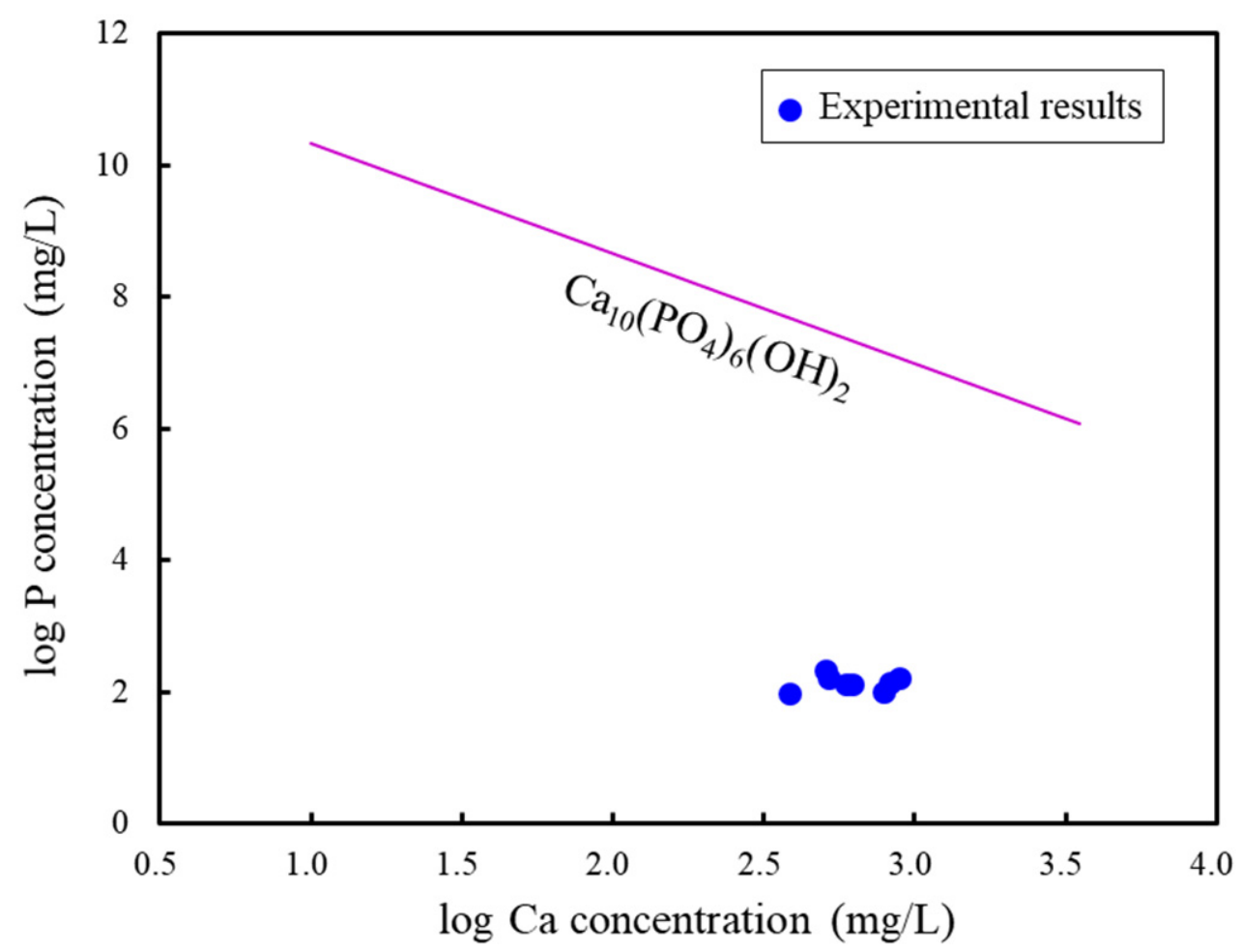

Figure 8. Relationship between $\mathrm{P}$ and Ca concentrations in the aqueous solution and experimental results.

As shown in Figure 9, most of the $P$ in slag was distributed in the $\mathrm{C}_{2} \mathrm{~S}_{-} \mathrm{C}_{3} \mathrm{P}$ solid solution. With the $\mathrm{P}_{2} \mathrm{O}_{5}$ content increased, the $\mathrm{P}$ distribution ratio in the solid solution decreased, suggesting that the slag with lower $\mathrm{P}_{2} \mathrm{O}_{5}$ content facilitated $\mathrm{P}$ enrichment. $70.8 \%$ of $\mathrm{P}$ in Slag 4 containing $16.3 \% \mathrm{P}_{2} \mathrm{O}_{5}$ was concentrated in the solid solution. Increasing $\mathrm{Fe}_{2} \mathrm{O}_{3}$ content was not beneficial for $\mathrm{P}$ enrichment. A higher slag basicity resulted in a higher $\mathrm{P}$ distribution ratio in the solid solution. For Slag 7 with low basicity, only half of the $\mathrm{P}$ in slag was distributed in the solid solution, which made it difficult to achieve $\mathrm{P}$-selective leaching. In each case, the $\mathrm{P}$ dissolution ratio from slag was a little lower than the P distribution ratio in the solid solution. Its variation tendency was the same as that of $\mathrm{P}$ distribution ratio. One reason for this was considered to be that a small part of P-concentrating solid solution was not dissolved. The other reason was that a small amount of $\mathrm{P}$ dissolved from slag precipitated with $\mathrm{Fe}^{3+}$ ions, resulting in a little decrease in $\mathrm{P}$ dissolution ratio. Although the $\mathrm{P}$ dissolution ratio was not very high, the effective dissolution of P-concentrating solid solution from quenched steelmaking slag was achieved under this condition, similar with the furnace-cooled slags as reported in previous studies [16-18].

To better understand selective leaching, we weighted the mass of remained residue and compared that with the mass fraction of matrix phase. As shown in Figure 10, a large amount of slag was not dissolved under this condition, and the mass fraction of residue was almost equal to that of matrix phase in each slag. This proved that the vast majority of P-concentrating solid solution was dissolved, and the dissolution of matrix phase was difficult, which was consistent with the residue analysis. For Slag 8 with high basicity, the mass fraction of solid solution was high, and then a large amount of slag was dissolved. In summary, the P dissolution ratio from slag was mainly determined by the $\mathrm{P}$ enrichment in the $\mathrm{C}_{2} \mathrm{~S}-\mathrm{C}_{3} \mathrm{P}$ solid solution and phosphate precipitation in the leachate. The P-concentrating solid solution was effectively dissolved and separated from quenched steelmaking slag when hydrochloric acid was used as leaching agent. 


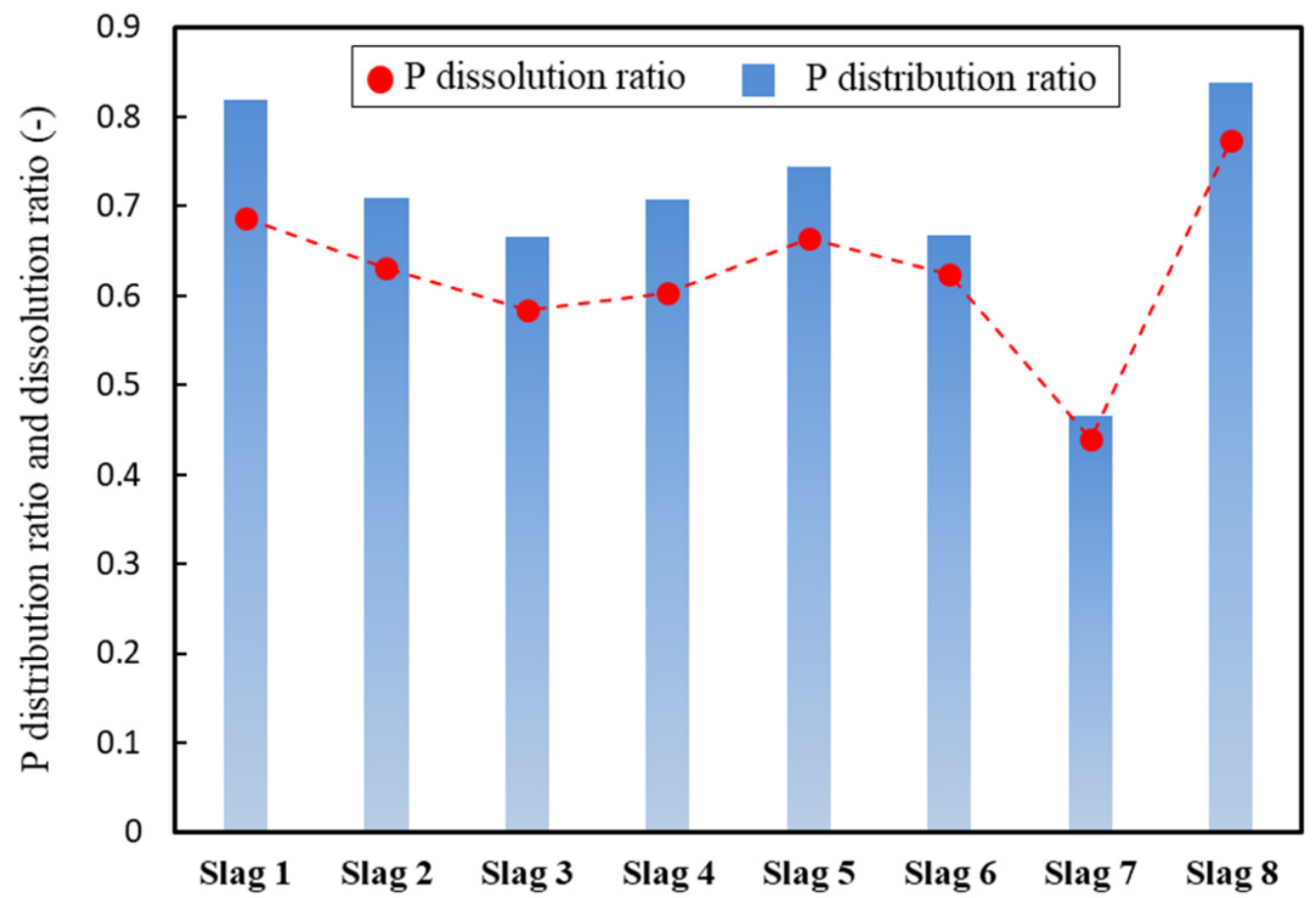

Figure 9. P distribution ratio in the solid solution compared with $\mathrm{P}$ dissolution ratio from slag.

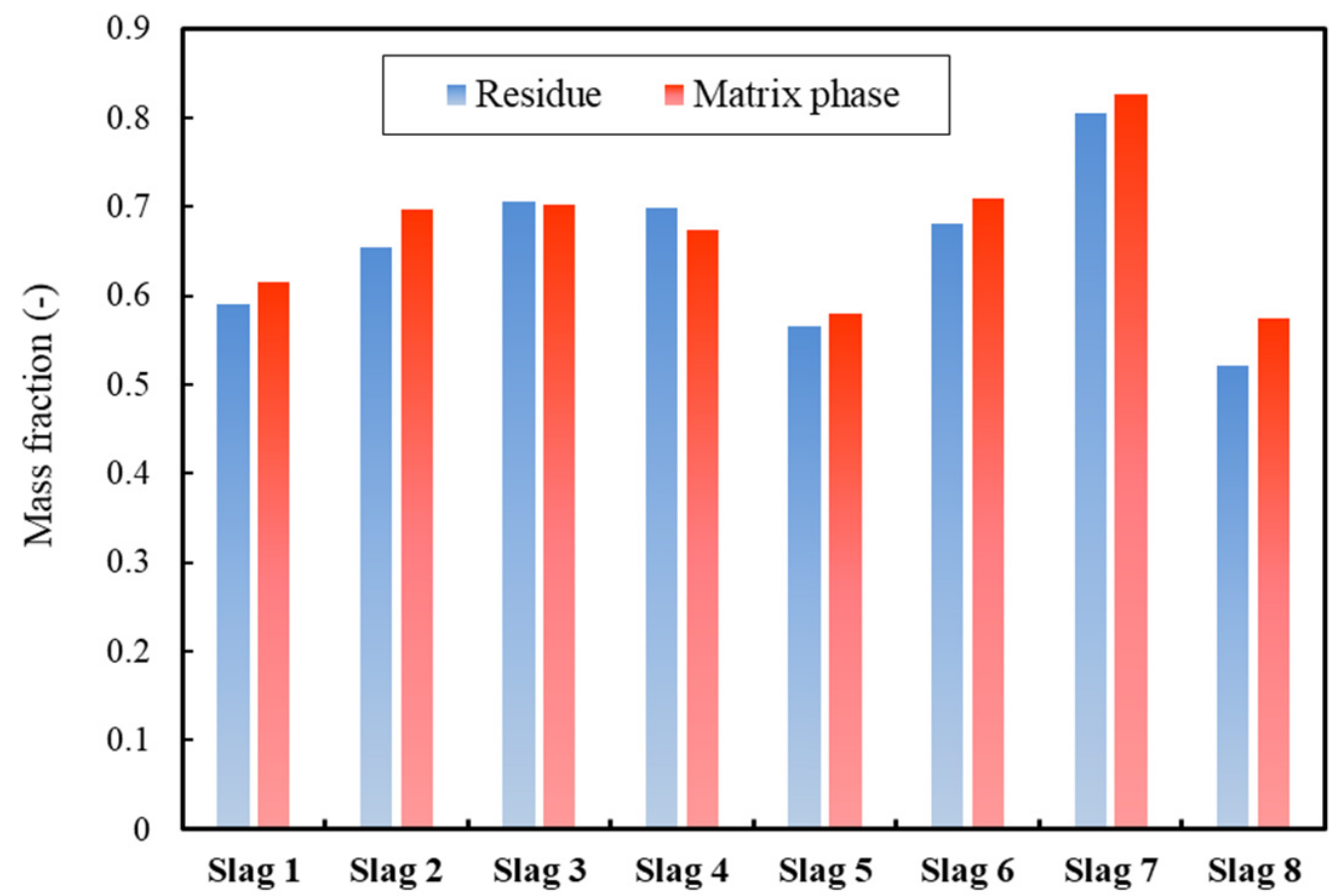

Figure 10. Mass fraction of matrix phase in each slag compared with that of residue.

\section{Conclusions}

To separate $\mathrm{P}$ from steelmaking slag using a simple and low-cost method, selective leaching of $\mathrm{C}_{2} \mathrm{~S}-\mathrm{C}_{3} \mathrm{P}$ solid solution was adopted, and hydrochloric acid was selected as leaching agent. In this study, the dissolution behavior of quenched steelmaking slags with different composition in the acidic solution was investigated. The results obtained are summarized below: 
(1) The P dissolution ratio from slag was higher than those of other elements in each case, achieving an effective separation of $\mathrm{P}$ and $\mathrm{Fe}$. The $\mathrm{C}_{2} \mathrm{~S}-\mathrm{C}_{3} \mathrm{P}$ solid solution was fully dissolved from slag, and then the residue primarily composed of the matrix phase, causing a significant decrease in $\mathrm{P}_{2} \mathrm{O}_{5}$ content.

(2) The dissolution ratios of $\mathrm{P}, \mathrm{Ca}$, and $\mathrm{Si}$ decreased as the $\mathrm{P}_{2} \mathrm{O}_{5}$ content in slag increased. A higher $\mathrm{Fe}_{2} \mathrm{O}_{3}$ content in slag resulted in a lower $\mathrm{P}$ dissolution ratio. Increasing slag basicity facilitated the dissolution of $\mathrm{P}$ from slag.

(3) The P dissolution ratio from slag was mainly determined by the P distribution ratio in the solid solution and the precipitation of ferric phosphate in the leachate. The P-concentrating solid solution was effectively separated from quenched steelmaking slag, even though hydrochloric acid was used as leaching agent, which provided a simple and low-cost method to recover valuable components from steelmaking slag.

Author Contributions: Conceptualization, C.-M.D. and N.-N.L.; methodology, C.-M.D.; investigation, H.K. and Y.-H.Y.; resources, N.-N.L. and C.-M.D.; writing-original draft preparation, N.-N.L.; writing-review and editing, C.-M.D., H.K., and Y.-H.Y.; All authors have read and agreed to the published version of the manuscript.

Funding: This work was Funded by the Open Project Program of Key Laboratory of Metallurgical Emission Reduction \& Resources Recycling (Anhui University of Technology), Ministry of Education (No. JKF20-01), Fundamental Research Funds for the Central Universities (No. N2025005), the National Natural Science Foundation of China (No. 52074004), and Director Fund of Anhui Province Key Laboratory of Metallurgical Engineering \& Resources Recycling (Anhui University of Technology).

Data Availability Statement: Data are contained within the article.

Conflicts of Interest: The authors declare no conflict of interest.

\section{References}

1. Matsubae-Yokoyama, K.; Kubo, H.; Nakajima, K.; Nagasaka, T. A material flow analysis of phosphorus in Japan. J. Ind. Ecol. 2009, 13, 687-705. [CrossRef]

2. Ogawa, Y.; Maruoka, N. Progress of hot metal treatment technology and future outlook. Tetsu Hagané 2014, 100, 434-444. [CrossRef]

3. Kitamura, S.; Naito, K.; Okuyama, G. History and latest trends in converter practice for steelmaking in Japan. Min. Proc. Ext. Met. 2019, 128, 34-45. [CrossRef]

4. Ito, K.; Yanagisawa, M.; Sano, N. Phosphorus distribution between solid $2 \mathrm{CaO} \cdot \mathrm{SiO}_{2}$ and molten $\mathrm{CaO}-\mathrm{SiO}{ }_{2}-\mathrm{FeO}-\mathrm{Fe} \mathrm{O}_{3}$ slags. Tetsu Hagane 1982, 68, 342-344. [CrossRef]

5. Kitamura, S.; Yonezawa, K.; Ogawa, Y.; Sasaki, N. Improvement of reaction efficiency in hot metal dephosphorization. Ironmak. Steelmak. 2002, 29, 121-124. [CrossRef]

6. Gao, X.; Okubo, M.; Maruoka, N.; Shibata, H.; Ito, T.; Kitamura, S.Y. Production and utilization of iron and steelmaking slag in Japan and the application of steelmaking slag for the recovery of paddy fields damaged by Tsunami. Min. Proc. Ext. Met. 2015, 124, 116-124.

7. Matsubae, K.; Yamasue, E.; Inazumi, T.; Webeck, E.; Miki, T.; Nagasaka, T. Innovations in steelmaking technology and hidden phosphorus flows. Sci. Total. Environ. 2016, 542, 1162-1168. [CrossRef] [PubMed]

8. Fix, W.; Heymann, H.; Heinke, R. Subsolidus relations in the system $2 \mathrm{CaO} \cdot \mathrm{SiO}_{2}-3 \mathrm{CaO} \cdot \mathrm{P}_{2} \mathrm{O}_{5}$. J. Am. Ceram. Soc. 1969, 52, 346-347. [CrossRef]

9. Zhu, B.; Zhu, M.M.; Luo, J.; Dou, X.F.; Wang, Y.; Jiang, H.J.; Xie, B. Distribution behavior of phosphorus in $2 \mathrm{CaO}^{-\mathrm{SiO}}{ }_{2}-3 \mathrm{CaO} \cdot \mathrm{P}_{2} \mathrm{O}_{5}$ solid solution phase and liquid slag phase. Metals 2020, 10, 1103. [CrossRef]

10. Li, C.; Gao, J.; Guo, Z. Separation of phosphorus- and iron-enriched phase from $\mathrm{CaO}-\mathrm{SiO}_{2}-\mathrm{FeO}-\mathrm{MgO}_{2} \mathrm{P}_{2} \mathrm{O}_{5}$ melt with super gravity. Metall. Mater. Trans. B 2016, 47, 1516-1519. [CrossRef]

11. Kubo, H.; Matsbuae-Yokoyama, K.; Nagasaka, T. Magnetic separation of phosphorus enriched phase from multiphase dephosphorization slag. ISIJ Int. 2010, 50, 59-64. [CrossRef]

12. Lin, L.; Bao, Y.P.; Wang, M.; Jiang, W.; Zhou, H.M. Separation and recovery of phosphorus from P-bearing steelmaking slag. J. Iron Steel Res. Int. 2014, 21, 496-502. [CrossRef]

13. Numata, M.; Maruoka, N.; Kim, S.; Kitamura, S. Fundamental experiment to extract phosphorous selectively from steelmaking slag by leaching. ISIJ Int. 2014, 54, 1983-1990. [CrossRef]

14. Qiao, Y.; Diao, J.; Liu, X.; Li, X.S.; Zhang, T.; Xie, B. Dephosphorization of steelmaking slag by leaching with acidic aqueous solution. JOM 2016, 68, 2511-2519. [CrossRef] 
15. Du, C.M.; Gao, X.; Ueda, S.; Kitamura, S. Effect of $\mathrm{Na}_{2} \mathrm{O}$ addition on phosphorus dissolution from steelmaking slag with high $\mathrm{P}_{2} \mathrm{O}_{5}$ content. J. Sustain. Metall. 2017, 3, 671-682. [CrossRef]

16. Du, C.M.; Gao, X.; Ueda, S.; Kitamura, S. Recovery of phosphorus from modified steelmaking slag with high $\mathrm{P}_{2} \mathrm{O}_{5}$ content via leaching and precipitation. ISIJ Int. 2018, 58, 833-841. [CrossRef]

17. Du, C.M.; Gao, X.; Ueda, S.; Kitamura, S. Optimum conditions for phosphorus recovery from steelmaking slag with high $\mathrm{P}_{2} \mathrm{O}_{5}$ content by selective leaching. ISIJ Int. 2018, 58, 860-868. [CrossRef]

18. Du, C.M.; Gao, X.; Ueda, S.; Kitamura, S. Effect of $\mathrm{Fe}^{2+} /$ T.Fe ratio on the dissolution behavior of $\mathrm{P}$ from steelmaking slag with high $\mathrm{P}_{2} \mathrm{O}_{5}$ content. J. Sustain. Metall. 2018, 4, 443-454. [CrossRef]

19. Teratoko, T.; Maruoka, N.; Shibata, H.; Kitamura, S. Dissolution behavior of dicalcium silicate and tricalcium phosphate solid solution and other phases of steelmaking slag in an aqueous solution. High. Temp. Mater. Processes. 2012, 31, 329-338. [CrossRef]

20. Lindsay, W.L.; Moreno, E.C. Phosphate phase equilibria in soils. Soil. Sci. Soc. Am. J. 1960, 24, 177-182. [CrossRef]

21. Shen, H.Y.; Wang, Z.J.; Zhou, A.M.; Chen, J.L.; Hu, M.Q.; Dong, X.Y.; Xia, Q.H. Adsorption of phosphate onto amine functionalized nano-sized magnetic polymer adsorbents: Mechanism and magnetic effects. RSC Adv. 2015, 5, 22080-22090. [CrossRef]

22. Markich, S.J.; Brown, P.L. Thermochemical Data for Environmentally-Relevant Elements; ANSTO Environment Division: Sydney, NSW, Australia, 1999.

23. Futatsuka, T.; Shitogiden, K.; Miki, T.; Nagasaka, T.; Hino, M. Dissolution behavior of nutrition elements from steelmaking slag into seawater. ISIJ Int. 2004, 44, 753-761. [CrossRef] 